\title{
DIAGNOSTICS OF CNC MACHINE TOOLS SPINDLE ERRORS
}

\section{DIAGNOSTYKA BŁĘDÓW WRZECION OBRABIAREK CNC}

\author{
Jerzy JÓŹWIK ${ }^{1}$
}

\begin{abstract}
The work presents characteristics and practical application of Spindle Error Analyzer, an innovative bespoke diagnostic system, designed for precision measurement of spindles used in high-precision $\mathrm{CNC}$ machining centers. Conducted tests exemplify that the process of diagnostics without high-precision and effectiveness methods and tools would be difficult. This results from high efficiency and kinematic standards and design complexity of modern machines. Modern engineering machines are equipped in spindles of increasing velocity capability and simultaneously accuracy of rotation, which therefore requires higherprecision bearings and headstock. Spindle bearings determine the geometric accuracy of axes of rotation, the setting of a rotating element, and are for those reasons the main contributing factor to the total error motion. Major applications of the system include: real-time monitoring of the spindle technical condition, potential spindle problem verification, spindle damage recognition (bearings, etc), evaluation of spindle condition at the stage of in-house testing and acceptance tests, verification of working order following crash. The present work analysed the capabilities and efficiency of precise detection of error motions (axial and radial) of the machine tool spindle and unique results of errors, measured by innovative Spindle Error Analyzer.

Keywords: spindle errors, diagnostics of CNC machine tools, monitoring of the spindle condition, geometric accuracy of axes of rotation
\end{abstract}

Streszczenie: Wrzeciono jest jednym z najważniejszych zespołów funkcjonalnych każdej obrabiarki skrawającej do metali. Wrzeciona i elektrowrzeciona współczesnych obrabiarek sterowanych numerycznie są skomplikowanymi układami mechatronicznymi napędu ruchu głównego. Od ich dokładności zależy jakość wytwarzanych części, a także wydajność obróbki, trwałość i dokładność całej obrabiarki CNC. Ich łożyska decydują o dokładności położenia osi obrotu, ustaleniu elementu wirującego i przenoszeniu sił skrawania. Jednocześnie należy stwierdzić, że ultraprecyzyjne i wysokoobrotowe wrzeciona należą do najbardziej kosztownych elementów obrabiarki CNC. Ich kontrola, diagnostyka i właściwa eksploatacja jest kluczowym zadaniem w każdym zakładzie przemysłowym. Diagnostyka dynamiczna wrzecion jest możliwa między innymi dzięki analizatorom błędów wrzecion.

\footnotetext{
${ }^{1}$ Lublin University of Technology, Mechanical Engineering Faculty, Department of Production Engineering, Nadbystrzycka Street 36, 20-816 Lublin, Poland, e-mail: j.jozwik@ pollub.pl
} 
Jednym z nich jest wykorzystany w pracy (zaprojektowany specjalnie na potrzeby oceny dokładności wrzecion stosowanych w precyzyjnych obrabiarkach CNC) SPINDLE ANALYZER firmy IBS Precision Engineering. Z analiz literatury wynika, że na dokładność obróbki wpływa nie tylko dokładność geometryczna obrabiarki, ale także zmienne w czasie obróbki błędne ruchy zastosowanego wrzeciona. W świetle obserwowanych trendów w konstrukcji obrabiarek i obróbki skrawaniem, stale dąży się do zwiększania prędkości skrawania i zwiększania możliwości wrzecion do osiągania coraz to wyższych prędkości obrotowych. Odgrywają one szczególnie ważną rolę w przypadku obróbki z dużą prędkością obrotową. Badania statyczne (przy nieruchomym wrzecionie lub przy wolnych obrotach) stają się niewystarczające do oceny odchyleń wrzeciona, które zachowuje się zupełnie inaczej w uwzględnianych w pracy warunkach dynamicznych, przy bardzo dużej wartości prędkości obrotowej. Przedstawione w pracy rozkłady całkowitych błędnych ruchów promieniowych synchronicznych i asynchronicznych oraz całkowitych mierzonych przemieszczeń promieniowych w warunkach wysokich obrotów pozwalają ocenić pośrednio stan łożysk, luzy, niedostateczną sztywność czy też niewyważenie.

Słowa kluczowe: błędy wrzeciona, diagnostyka obrabiarek CNC, nadzorowanie stanu wrzeciona, dokładność geometryczna osi obrotu

\section{INTRODUCTION}

The machining industry demands the application of various technologies for machine elements manufacturing. Many of those technologies have been in use for certain time, e.g.: material removal, plastic working (forming), high-molecular material machining, assembly, welding or casting. Each of these technologies is frequently developed into new, hybrid and innovative methods, such as: friction drilling, ultrasonic burnishing, ultrasonic machining, laser texturing, thermal assisted machining (laser or plasma), machining with cryogenic heat treatment of the tool with liquid nitrogen or $\mathrm{CO}_{2}$, hard machining, etc. These demand accurate and precise machines, which enable high speed with simultaneous high precision of machining. In addition, it is essential to provide proper diagnostics for high-precision measurements of tools, such as a spindle [1]. Practice shows that innovative solutions in machining are not solely limited to manufacturing methods and include innovation in tools and diagnostic systems [1].

The present work presents characteristics and practical application of Spindle Error Analyzer, an innovative bespoke diagnostic system, designed for precision measurement of spindles used in high-precision CNC machining centres [42,43]. The Spindle Error Analyzer performs tests in compliance with the following standards: ANSI/ASME Standard B5.54-2005, Methods for Performance Evaluation of CNC Machining Centers, ANSI/ASME B5.57-1998, Methods for Performance Evaluation of CNC Turning Centers, ANSI/ASME B89.3.4-2010, Axes of Rotation, Methods for Specifying and Testing, ISO230-3, Test Code for Machine Tools Part 3, Determination of Thermal Effects, ISO230-7, Test Code for Machine Tools Part 7, Geometric Accuracy of Axes of Rotation, JIS B 6190-7, Test Code for Machine Tools Part 7, Geometric Accuracy of Axes of Rotation [42]. Virtually all of the aforementioned milling methods require the application of a spindle, which is for that reason one of the most essential functional units of a metal machining tool. Spindles and electrospindles in modern numerically controlled machining centres comprise a highly complex mechatronic system of the main drive. Their precision has a paramount impact on the machined part accuracy, 
machining efficiency, durability and precision of the entire CNC machine. The bearings determine geometric accuracy of axes of rotation, the setting of a rotating element - most frequently the tool, and absorption of milling forces. Notably, ultra-precise and high-speed spindles constitute one of the most expensive elements of the CNC machine tool. Their control, diagnostics and proper use should be the matter of utmost importance at any production plant. Dynamic diagnostics of spindles is possible partly due to spindle error analysers. [11-14,19,22-26,30,34,36,38-43]. Literature analysis indicates that, however important, geometric accuracy of the machining tool alone does not ensure high precision of machining, as spindle error motion is of great significance [10-14] . In the light of observed trends in machine tool construction and machine cutting in general, the tendency is towards increasing machining velocity and adapting spindles for increasingly higher speeds. Therefore spindles are of great importance, particularly in high-speed machining. Static measurements, conducted at low or zero speed, have become inadequate for the determination of the tilt of the spindle, which behaves considerably different in dynamic conditions, when the rotational speed amount to considerable values. The disposition of synchronous and asynchronous error motions and radial runout measured at high RPM enables, indirectly, evaluation of bearings condition, backlash, insufficient stiffness or unbalance [38-43].

\section{EXPERIMENTAL TESTS}

\subsection{TEST STAND}

As it was remarked in the opening section, spindle diagnostics was performed with Precision Spindle Error Analyzer (Fig. 1).

a)

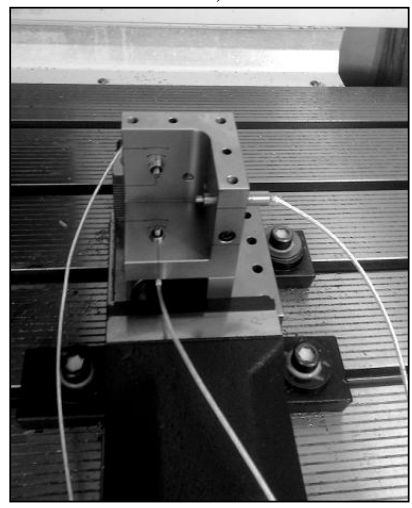

b)

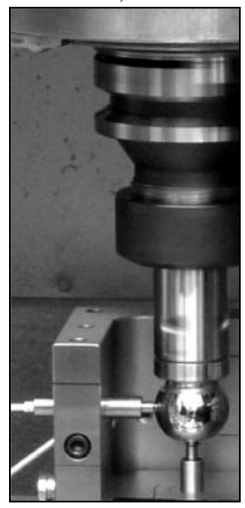

c)

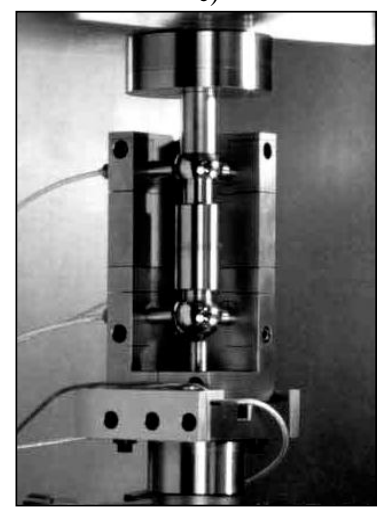

Figure 1. Precision Spindle Error Analyzer: a) three-capacitive-sensor system version,

b) setup of three-capacitive-sensor system [42]

c) setup of five-capacitive-sensor system version $[42,43]$

The measurements were taken with strict adherence to the most recent norm ISO 230 (ISO 230-7). Dynamic radial measurement of a 3-axis CNC DMC 635 eco numerically controlled machining centre was conducted (Fig. 2). 
a)

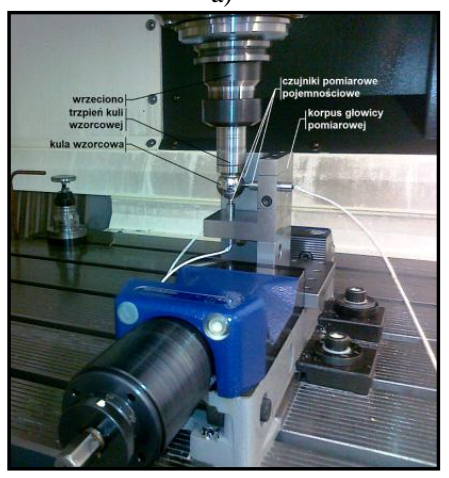

b)

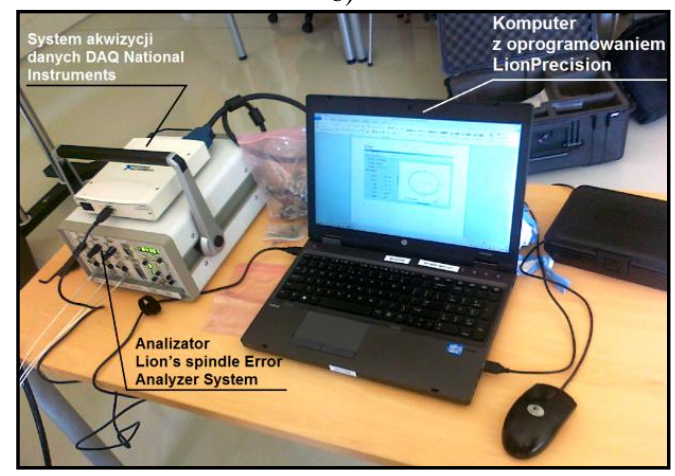

Figure 2. Test stand: a) mounting probes and master ball on machine tool, b) data analyser with LionPrecision software

Test stand for the diagnosed CNC machine tool spindle accuracy measurement (Fig. 2) consisted of the following modules of the measuring apparatus:

- the measuring head consisting of 3 probes (Figs. 1a,b and Fig. 2a) mounted in numerically controlled X, Y axes of the machine tool (Driver CPL-290, frequency of $15 \mathrm{kHz}$, range of $250 \mu \mathrm{m}$, resolution of $3.5 \mathrm{~nm}$ RMS); a 5-probe system version is possible (Fig. 1c);

- National Instruments data acquisition system (Lion Precision uses NI LabWindows ${ }^{\mathrm{TM}} / \mathrm{CVI}$ software and USB DAQ hardware to determine machine capability) (Fig. 3);

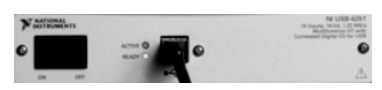

Figure 3. DAQ data acquisition board [42]

- Lion's Spindle Error Analyzer System managing the 3-probe measuring system with LionPrecision software (Fig. 4);

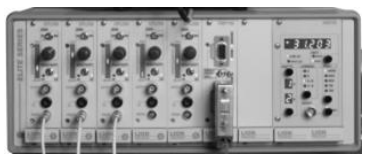

Figure 4. Lion's data analyser [42]

- a $25.4 \mathrm{~mm}$ diameter (1 in) master ball, roundness spec of $<50 \mathrm{~nm}$, which practically eliminates surface roundness error (Fig. 1b).

The master ball is mounted in the spindle tool holder of the analysed DMC 635 eco machining centre. The spindle motions are measured in three directions $\mathrm{X}, \mathrm{Y}, \mathrm{Z}$ with precise capacitive sensors mounted in a common probe nest. The system is mounted on the table of the machine to form a specific measuring head.

In the case of the vertical spindle, additional sensors are responsible for particular radial and axial error measurements: 
- sensor 1: radial motion error in the $\mathrm{X}$ axis (horizontal plane),

- sensor 2: radial motion error in the Y axis (horizontal plane),

- sensor 3: axial motion error in the $\mathrm{Z}$ axis (vertical plane) (Fig. 1).

Although the spindle axis is a theoretical notion, what can be analysed is instantaneous axis of rotation. At higher RPM values the impact of motion dynamics related forces on instantaneous rotation axis is profound. Frequently, the measurement is taken in the spindle tip. In the conditions of ideal position of rotation axis and perfect roundness quality of the measurement surface plot show a sinusoid, representing eccentricity of the measurement surface to rotation axis. Error motions represent instantaneous axis displacement.

\subsection{MEASURED ERRORS}

Precision Spindle Error Analyzer used in the tests is capable of conducting dynamic spindle errors and thermal drift measurement. The described tests required the application of dynamic spindle performance measurement method developed by Prof. Tlusty, and included in the ISO 230-7:2006 standard. The sampling method in question consists in real-time measurement with non-contact precision displacement sensors. In addition, it enables diagnostics of motion errors in the $\mathrm{X}$ - and $\mathrm{Y}$ - direction while the spindle is turning, for a desired master RPM value. All measurements are conducted according to the ISO 230-7 norm. Special algorithms implemented in the software enable determination of a number of parameters regarding spindle accuracy, such as:

- synchronous error motion,

- asynchronous error motion,

- TIR total indicated read-out,

- total error motion,

- shift versus RPM,

- thermal drift. [38-40].

Measurement results are presented in graphic and numerical form. Figure 5 shows the interface of the system used in measurements, which presents radial (Fig. 5a) and axial error measurement results (Fig. 5b) of the spindle, together with figure values of these errors. Figure 5 presents a model instantaneous axis of rotation as a function of rotation angle in polar plots for the velocity of 2000 RPM, measured in 4 spindle rotations.

Synchronous Error Motion indicates roundness (out-of-roundness) of machined surfaces. The synchronous motion of the spindle (synchronised with the rotational speed) is described by a set of values obtained from the calculation of mean angular value at each discreet angular position. Then, the difference between the radius of circumscribing circle and the inscribing circle on the mean length between the axis of rotation and the centre of the system is precisely defined as a synchronous error motion of the axis. In such a case it is necessary to check and eliminate spindle error motions generated by race roundness error or bearing holder position. Appearance of radial errors on axial or radial error diagrams indicates deterioration of machined surface state, which could result from bearing race damage. Synchronous error motion is a sign of incorrect initial bearing preload or bearing holder position. This error results in deterioration of machined surface quality. 
a)

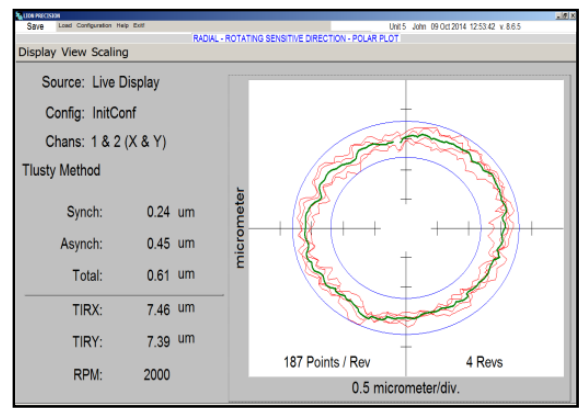

b)

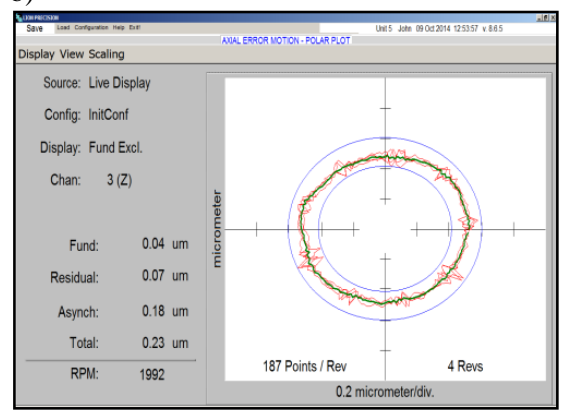

Figure 5. Precision Spindle Error Analyzer user interface,

presenting measurement results at 2000 RPM of a) radial errors, b) axial errors

Asynchronous Error Motion enables evaluation of instantaneous rotation axis repeatability. It is measured in several spindle rotations and the result is subsequently averaged. It is obtained when maximum and minimum angle values are calculated, to produce minimum and maximum rotary axis error, which correspond to each angular position. The error in question can therefore be interpreted as maximum amplitude of transverse vibrations of the axis in rotation to angular position. Graphical representation of the synchronous and asynchronous error motions is shown in Figure 6.

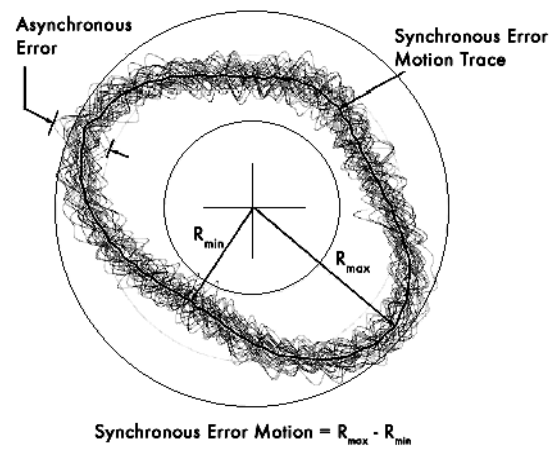

Figure 6. Graphical representation of synchronous and asynchronous error motion [42]

Runout (total indicated read-out TIR) represents maximum recorded radial displacement in the direction of displacement sensor. Determined TIR parameter comprises: eccentricity of measurement surface to rotation axis, geometric errors of the measurement surface, axis motion errors in the direction of measurement, resulting from unbalance, stiffness or dynamic properties (i.e. natural frequency) dynamic error of headstock or measurement noise.

Total Error Motion represents maximum amplitude of instantaneous spindle axis errors from the coordinate system defined by the following equation (1).

$$
\sum_{i=1}^{N}\left[\left(x_{i}^{\prime}-x_{0}\right)^{2}+\left(y_{i}^{\prime}-y_{0}\right)^{2}-r_{0}^{2}\right]=\min
$$


where:

$\mathrm{r}_{0}$ - circle radius corresponding to eccentricity of measurement surface,

$\mathrm{x}_{0}, \mathrm{y}_{0}$ - coordinates of the circle centre,

$\mathrm{x}^{\prime}{ }_{\mathrm{i}}, \mathrm{y}_{\mathrm{i}}{ }_{\mathrm{i}}-$ results of subsequent measurements (sensor readings are translated to $\mu \mathrm{m}$ ).

Coordinates of the centre of the circle are determined from sensor settings. These determine the real centre of the coordinates system, to which all measurement results are correlated.

$$
\begin{aligned}
& X=X^{\prime}-x_{0} \\
& Y=Y^{\prime}-y_{0}
\end{aligned}
$$

where:

$$
\begin{aligned}
& \mathrm{X}^{\prime} \text { - sensor readings in the } \mathrm{X} \text { - axis direction, } \\
& \mathrm{Y} \text { ' - sensor readings in the } \mathrm{Y} \text { - axis direction, } \\
& \mathrm{X} \text { - vector of spindle motion in the } \mathrm{X} \text { - direction, } \\
& \mathrm{Y} \text { - vector of spindle motion in the } \mathrm{Y} \text { - direction. }
\end{aligned}
$$

Sensor readings ( $\left.\mathrm{X}^{\prime}, \mathrm{Y}^{\prime}\right)$ (as vectors $\mathrm{X}^{\prime}$ and $\mathrm{Y}^{\prime}$ ) determine the circle which represents the motion of a rotating spindle so that the sum of squared displacements from the circle was the lowest (the so-called least squares circle).

Shift versus RPM is the change of the axis of rotation resulting from RPM change. It can occur as axial shift (shift in the axis of rotation parallel to the $\mathrm{Z}$ reference axis), radial shift (shift in the axis of rotation perpendicular to the $Z$ reference axis), tilt shift (shift in the axis of rotation relative to the $\mathrm{Z}$ reference axis) and face shift (combination of axial and tilt shifts in the axis of rotation measured at a specified location).

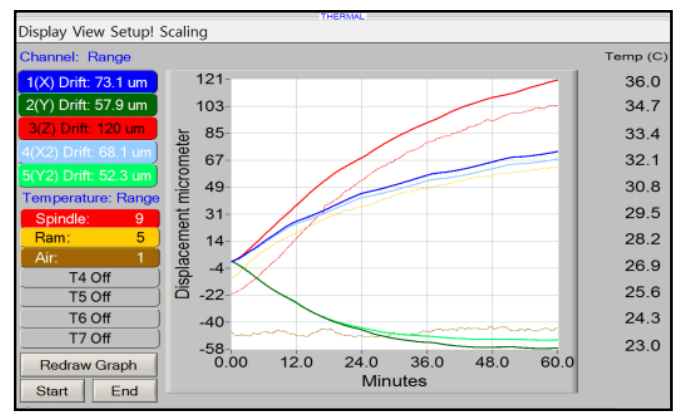

Figure 7. Thermal drift of numerically controlled machine spindle [42, 43]

Thermal drift is determined according to the methodology described in the norm ISO 2303:2007 as a function of time. This error denotes displacement in the particular (numerically controlled) perpendicular axes $\mathrm{X}, \mathrm{Y}, \mathrm{Z}$ as a result of elevated temperature of the rotating spindle over time. The test for the measurement of thermal drift is conducted over a considerable period of time, e.g. $300 \mathrm{~min}$. Model characteristics of machine spindle thermal drift in the period of 60 min are presented in Figure 7. 


\subsection{TEST SEQUENCE}

The tests consisted in spindle error measurement at idle state, i.e. the machine is operating, motion axes are active and spindle is rotating with no-load.

a)

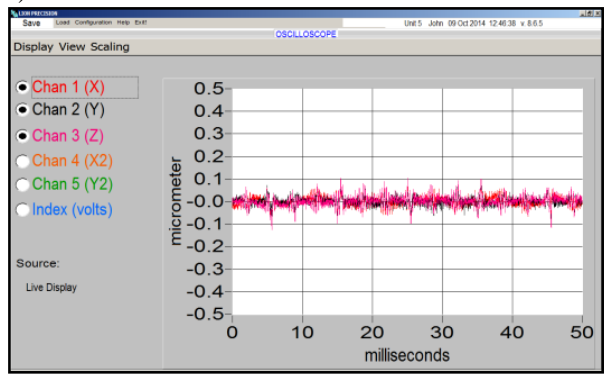

b)

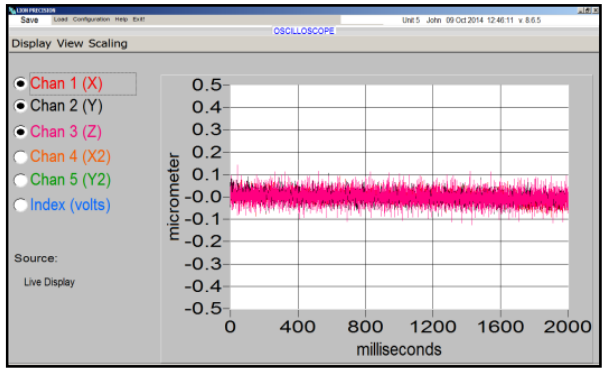

Figure 8. Signal from sensors for spindle error measurement at idle run: a) $50 \mathrm{~ms}$, b) $2000 \mathrm{~ms}$

The measurements were conducted to verify the correctness of the following assemblies: spindle-master ball, measuring head-measuring table, as well as excessive internal and external vibration in the machine-clamp-piece-tool system, electromagnetic interference, the presence of electric sources of error. Figure 8 presents the changes of signal for the idle run measurements as a function of time, in the range of $50 \mathrm{~ms}$ (Fig. 8a) and $2000 \mathrm{~ms}$ (Fig. 8b).The presented characteristics indicate that the stability of the signal is high, with the amplitude $<0.1 \mu \mathrm{m}$. The second stage consisted in a quasi-static measurement to control the measuring system and all channels at slow spindle rotation speed of 100 RPM.

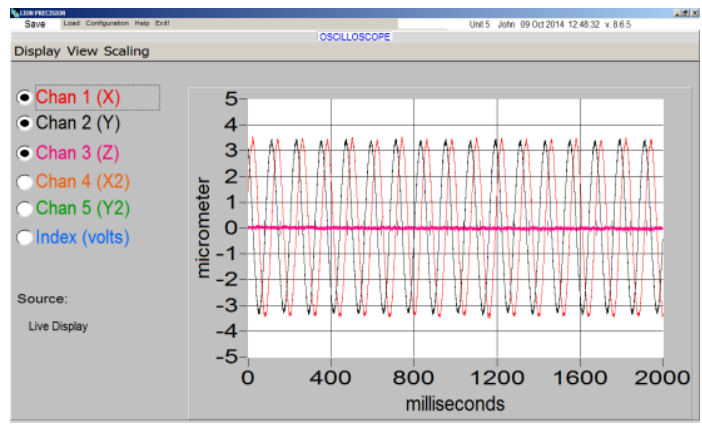

Figure 9. Runout at idle run

The changes of runout presented in Figure 9 indicate that due to the fact that the parameter in question is $>3.5 \mu \mathrm{m}$ for all sensors over a long period of time the machine run is stable.

\section{TEST RESULTS}

The subsequent stage consisted in dividing the $0-8000$ RPM in 8 ranges at a 1000 RPM step (Table 1). The calibrated system was subsequently dynamically tested at different RPM values in the aforementioned ranges. The tests in question were carried out and their results 
interpreted in compliance with ISO 230-7 norm guidelines. Test results obtained in the set ranges are collated in Table 1. Maximum values of particular errors are additionally boxed. The measurement results indicate that the highest value of total indicated read-out was observed in the range of 4000-5000 RPM (4500 RPM and 5000 RPM), whereas other errors peaked at RPM values range of 7000-8000 (7500 RPM and 8000 RPM).

Although the observed correlation between radial and axial errors of the spindle motion is non-linear, the tendency of changes demonstrates a raising, non-linear character in the case of the majority of analysed errors, with the exception of TIR. Total indicated read-out of the analysed spindle amounts to $2.79-8.49 \mu \mathrm{m}$ peaking at $5000 \mathrm{RPM}$, within the full range of RPM speeds (0-8000 RPM).

Negligible TIR error value indicates insignificant eccentricity of the tool holder or the axis of rotation of the spindle. Synchronous error is within $0.26-1.51 \mu \mathrm{m}$ (at 7000-8000 RPM), while asynchronous error in the range of 6000-7000 RPM was recorder within the 0.10$1.51 \mu \mathrm{m}$ range. Low values of synchronous error may result from slightly incorrect bearing holder position or initial bearing preload.

Table 1. Spindle motion errors of a 3-axis numerically controlled machining centre CNC DMC 635 eco

\begin{tabular}{|c|c|c|c|c|c|c|c|}
\hline \multirow{4}{*}{ Error } & \multirow{4}{*}{$\begin{array}{l}\text { Range } \\
\text { of RPM }\end{array}$} & \multicolumn{6}{|c|}{ Value of error motion $[\mu \mathrm{m}]$} \\
\hline & & \multicolumn{3}{|c|}{ for $50 \% \mathrm{RPM}$ of range } & \multicolumn{3}{|c|}{ for $100 \%$ RPM of range } \\
\hline & & \multicolumn{2}{|c|}{$\begin{array}{l}\text { Radial errors } \\
\text { motion }[\mu \mathrm{m}]\end{array}$} & \multirow{2}{*}{$\begin{array}{c}\text { Axial errors } \\
\text { motion }[\mu \mathrm{m}] \\
\mathrm{Z}\end{array}$} & \multicolumn{2}{|c|}{$\begin{array}{c}\text { Radial errors motion } \\
{[\mu \mathrm{m}]}\end{array}$} & \multirow{2}{*}{$\begin{array}{c}\text { Axial errors } \\
\text { motion }[\mu \mathrm{m}] \\
\mathrm{Z}\end{array}$} \\
\hline & & $\mathrm{X}$ & $\mathrm{Y}$ & & $\mathrm{X}$ & $\mathrm{Y}$ & \\
\hline \multirow{8}{*}{$\begin{array}{l}\text { TIR: total } \\
\text { indicated } \\
\text { read-out }\end{array}$} & 0000-1000 & 7.14 & 7.08 & $x$ & 7.14 & 7.32 & $x$ \\
\hline & $1000-2000$ & 7.43 & 7.12 & $x$ & 7.76 & 7.39 & $x$ \\
\hline & $2000-3000$ & 7.57 & 7.29 & $x$ & 7.75 & 7.07 & $\hat{x}$ \\
\hline & $3000-4000$ & 8.14 & 7.30 & $\begin{array}{l}x \\
x\end{array}$ & 8.01 & 7.47 & $\begin{array}{l}x \\
x\end{array}$ \\
\hline & $4000-5000$ & 8.49 & 7.60 & $x$ & 8.29 & 7.80 & $x$ \\
\hline & $5000-6000$ & 8.21 & 7.56 & $\hat{x}$ & 6.60 & 7.32 & $\hat{x}$ \\
\hline & $6000-7000$ & 5.65 & 6.92 & $\hat{x}$ & 4.07 & 7.23 & $x$ \\
\hline & $7000-8000$ & 2.73 & 6.70 & $\hat{x}$ & 3.60 & 7.33 & $\hat{x}$ \\
\hline \multirow{8}{*}{$\begin{array}{l}\text { Synch: } \\
\text { synchronous } \\
\text { error motion }\end{array}$} & $0000-1000$ & \multirow{8}{*}{\multicolumn{2}{|c|}{$\begin{array}{l}0.26 \\
0.30 \\
0.52 \\
0.81 \\
0.66 \\
1.30 \\
1.85 \\
2.77 \\
\end{array}$}} & $\mathrm{x}$ & \multirow{8}{*}{\multicolumn{2}{|c|}{$\begin{array}{l}0.41 \\
0.24 \\
0.39 \\
0.68 \\
0.88 \\
1.27 \\
2.37 \\
3.08 \\
\end{array}$}} & $x$ \\
\hline & $1000-2000$ & & & $x$ & & & $x$ \\
\hline & $2000-3000$ & & & $x$ & & & $x$ \\
\hline & $3000-4000$ & & & $\hat{x}$ & & & $x$ \\
\hline & $4000-5000$ & & & $\hat{x}$ & & & $\hat{x}$ \\
\hline & $5000-6000$ & & & $\begin{array}{l}x \\
x\end{array}$ & & & $\hat{x}$ \\
\hline & $6000-7000$ & & & 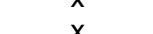 & & & 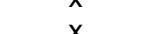 \\
\hline & $7000-8000$ & & & $\begin{array}{l}x \\
x\end{array}$ & & & $\begin{array}{l}x \\
x\end{array}$ \\
\hline \multirow{8}{*}{$\begin{array}{l}\text { Asynch: } \\
\text { asynchronous } \\
\text { error motion }\end{array}$} & 0000-1000 & & 0.13 & \multicolumn{2}{|c|}{0.37} & 0.14 \\
\hline & $1000-2000$ & \multicolumn{2}{|c|}{0.30} & 0.17 & \multicolumn{2}{|c|}{0.45} & 0.18 \\
\hline & $2000-3000$ & \multicolumn{2}{|c|}{0.46} & 0.12 & \multicolumn{2}{|c|}{0.50} & 0.10 \\
\hline & $3000-4000$ & \multicolumn{2}{|c|}{0.62} & 0.11 & \multicolumn{2}{|c|}{0.48} & 0.16 \\
\hline & $4000-5000$ & \multicolumn{2}{|c|}{0.40} & 0.17 & \multicolumn{2}{|c|}{0.48} & 0.12 \\
\hline & $5000-6000$ & \multicolumn{2}{|c|}{0.66} & 0.11 & \multicolumn{2}{|c|}{0.57} & 0.13 \\
\hline & $6000-7000$ & \multicolumn{2}{|c|}{1.42} & 0.20 & \multicolumn{2}{|c|}{1.51} & 0.13 \\
\hline & $7000-8000$ & \multicolumn{2}{|c|}{0.88} & 0.20 & & & 0.08 \\
\hline
\end{tabular}

Asynchronous errors, on the other hand, could be a result of minor axial or radial backlash, unbalance or stiffness. The inconsiderable values of basic, total and residual errors evidence good technical condition of the analysed spindle. In addition, relative stability of the rotating 
spindle was observed. The highest discrepancy between the master and actual RPM value was noted at 500 RPM and was recorded with X,Y radial sensors. In the analysed case the difference, axially measured with sensor 3, was equal to 50 RPM and amounted to 55 RPM at the speed of 7000 RPM.

The remaining values of spindle RPM residue were recorded in the range of $0 \div 30 \mathrm{RPM}$. Figure 10 is the graphical representation of radial error motion measurement results in the horizontal plane (X\&Y) with the Precision Spindle Error Analyzer (SEA) for the selected values of spindle revolution velocity: 500 RPM (Fig. 10a) and 7000 RPM (Fig. 10b).

Table 1. (continued)

\begin{tabular}{|c|c|c|c|c|c|}
\hline $\begin{array}{l}\text { Fund: } \\
\text { Fundamental } \\
\text { error motion }\end{array}$ & $\begin{array}{l}0000-1000 \\
1000-2000 \\
2000-3000 \\
3000-4000 \\
4000-5000 \\
5000-6000 \\
6000-7000 \\
7000-8000\end{array}$ & $\begin{array}{l}x \\
x \\
x \\
x \\
x \\
x \\
x \\
x\end{array}$ & $\begin{array}{l}0.02 \\
0.07 \\
0.06 \\
0.06 \\
0.12 \\
0.36 \\
0.87 \\
0.92 \\
\end{array}$ & $\begin{array}{l}\mathrm{x} \\
\mathrm{x} \\
\mathrm{x} \\
\mathrm{x} \\
\mathrm{x} \\
\mathrm{x} \\
\mathrm{x} \\
\mathrm{x}\end{array}$ & $\begin{array}{l}0.01 \\
0.04 \\
0.07 \\
0.41 \\
0.34 \\
0.70 \\
0.65 \\
0.98 \\
\end{array}$ \\
\hline $\begin{array}{l}\text { Residual: } \\
\text { residual error } \\
\text { motion }\end{array}$ & $\begin{array}{l}0000-1000 \\
1000-2000 \\
2000-3000 \\
3000-4000 \\
4000-5000 \\
5000-6000 \\
6000-7000 \\
7000-8000\end{array}$ & $\begin{array}{l}x \\
x \\
x \\
x \\
X \\
x \\
x \\
x\end{array}$ & $\begin{array}{l}0.09 \\
0.08 \\
0.08 \\
0.09 \\
0.12 \\
0.20 \\
0.13 \\
0.22 \\
\end{array}$ & $\begin{array}{l}x \\
x \\
x \\
x \\
x \\
x \\
x \\
x\end{array}$ & $\begin{array}{l}0.10 \\
0.07 \\
0.16 \\
0.09 \\
0.11 \\
0.11 \\
0.19 \\
0.19 \\
\end{array}$ \\
\hline $\begin{array}{l}\text { Total: total error } \\
\text { motion }\end{array}$ & $\begin{array}{l}0000-1000 \\
1000-2000 \\
2000-3000 \\
3000-4000 \\
4000-5000 \\
5000-6000 \\
6000-7000 \\
7000-8000\end{array}$ & $\begin{array}{l}0.38 \\
0.61 \\
0.78 \\
1.08 \\
0.93 \\
1.65 \\
2.35 \\
3.14 \\
\end{array}$ & $\begin{array}{l}0.22 \\
0.22 \\
0.23 \\
0.21 \\
0.34 \\
0.52 \\
1.00 \\
1.08 \\
\end{array}$ & $\begin{array}{l}0.55 \\
0.61 \\
0.87 \\
0.91 \\
1.15 \\
1.64 \\
3.34 \\
3.36 \\
\end{array}$ & $\begin{array}{l}027 \\
0.23 \\
0.19 \\
0.57 \\
0.45 \\
0.75 \\
0.79 \\
1.11 \\
\end{array}$ \\
\hline & Range of RPM & $\begin{array}{l}\text { Measured } \\
\text { RPM }\end{array}$ & $\begin{array}{c}\text { Measured } \\
\text { RPM }\end{array}$ & $\begin{array}{c}\text { Measured } \\
\text { RPM }\end{array}$ & $\begin{array}{c}\text { Measured } \\
\text { RPM }\end{array}$ \\
\hline $\begin{array}{l}\text { RPM: } \\
\text { revolutions per } \\
\text { minute }\end{array}$ & $\begin{array}{l}0000 \div 1000 \\
1000 \div 2000 \\
2000 \div 3000 \\
3000 \div 4000 \\
4000 \div 5000 \\
5000 \div 6000 \\
6000 \div 7000 \\
7000 \div 8000\end{array}$ & $\begin{array}{l}450 \\
1500 \\
2496 \\
3497 \\
4503 \\
5510 \\
6504 \\
7500\end{array}$ & $\begin{array}{c}500 \\
1503 \\
2492 \\
3497 \\
4492 \\
5496 \\
6504 \\
7481\end{array}$ & $\begin{array}{l}1001 \\
2000 \\
3000 \\
4010 \\
5013 \\
5985 \\
7018 \\
8000\end{array}$ & $\begin{array}{c}999 \\
1992 \\
3006 \\
3990 \\
5000 \\
5970 \\
7055 \\
7973\end{array}$ \\
\hline
\end{tabular}



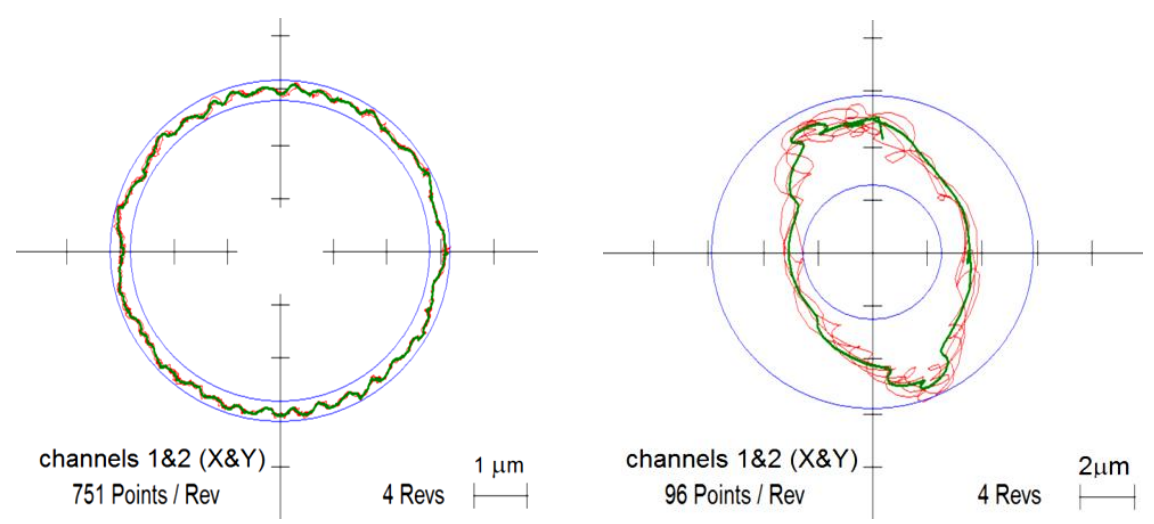

Figure 10. Graphical representation of radial error motion measurement in horizontal plane (X\&Y) with Precision Spindle Error Analyzer (SEA),

for selected spindle revolution velocity: a) 500 RPM, b) 7000 RPM

Figure 11 shows graphical representation of axial error motion errors of the spindle in the horizontal plane (X\&Y) conducted with the Precision Spindle Error Analyzer (SEA), for the selected spindle revolution velocity of: 500 RPM (Fig. 11a) and 7000 RPM (Fig. 11b).
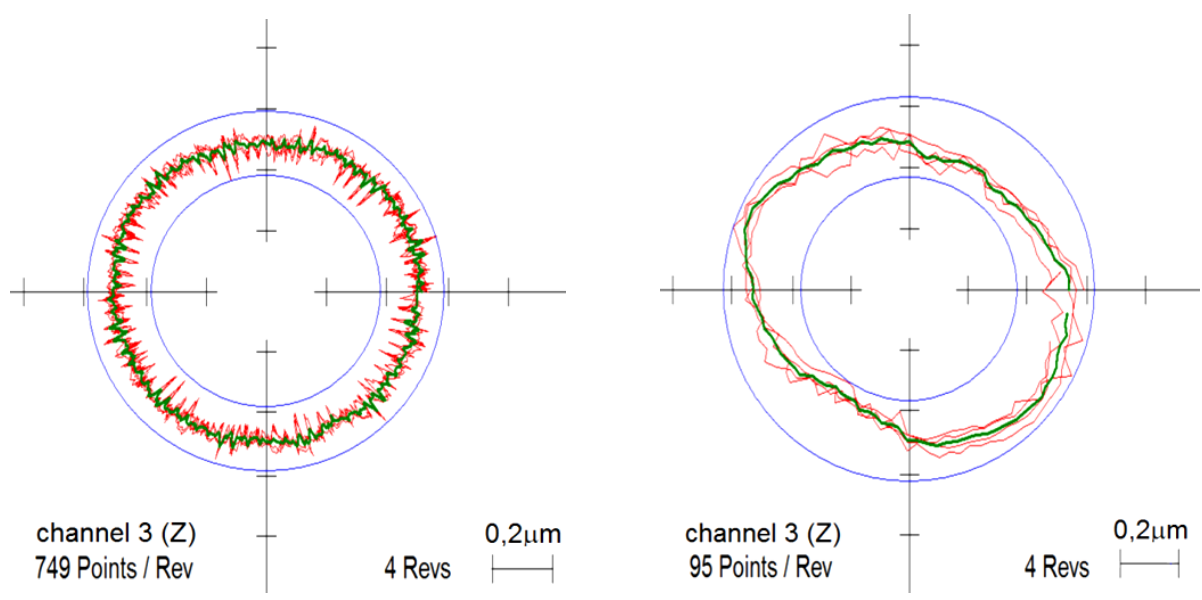

Figure 11. Graphical representation of axial error motion measurement in vertical plane (Z) with Precision Spindle Error Analyzer (SEA), for selected spindle revolution velocity: a) 500 RPM, b) 7000 RPM

Figure 12 presents shift vs. RPM in X,Y,Z axis. Measurement data indicates the shift in the $\mathrm{X}$ - axis direction was $>0.33 \mu \mathrm{m}, \mathrm{Y}>0.49 \mu \mathrm{m}$ and $\mathrm{Z}>1.6 \mu \mathrm{m}$. 


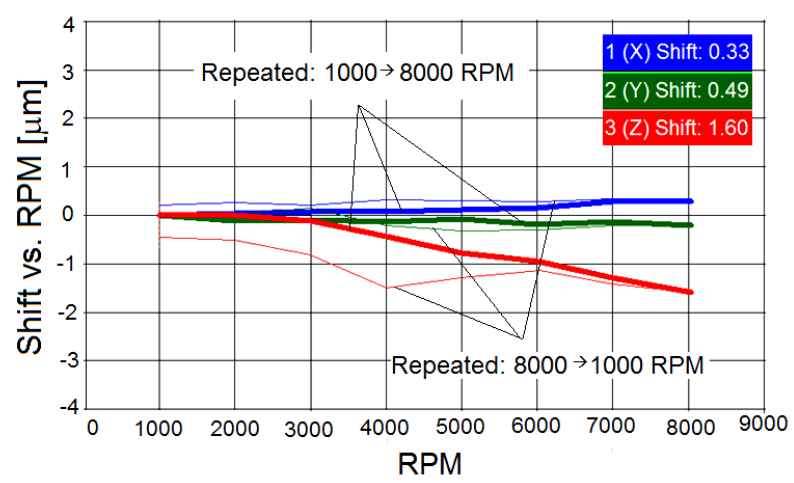

Figure 12. Graphical representation of shift vs. RPM measurements with Precision Spindle Error Analyzer (SEA), in spindle revolution velocity range of 1000-8000 RPM

The presented test can be moreover used for the evaluation of actual state of initial spindle bearing preload. In such a case spindle tilt in the X-, Y- and Z- directions (Fig. 12) is measured at increasing spindle revolution velocity in very short time. Due to the fact that the increase of RPM increases mechanical load in the spindle unit (i.e. centrifugal force and initial preload) spindle position shift, per revolution, is observed.

\section{SUMMARY AND CONCLUSIONS}

Early and effective diagnostics of numerically controlled machine tool spindle is crucial to maintaining their constant and high technical efficiency. Conducted tests exemplify that the process of diagnostics without high-precision and effectiveness methods and tools would be difficult. This results from high efficiency and kinematic standards and design complexity of modern machines. Modern engineering machines are equipped in spindles of increasing velocity capability and simultaneously accuracy of rotation, which therefore requires higherprecision bearings and headstock. Spindle bearings determine the geometric accuracy of axes of rotation, the setting of a rotating element, and are for those reasons the main contributing factor to the total error motion.

It has been recently observed that the dynamics of rotation, rather than geometric accuracy, have greater impact on machining precision, hence the methods of high-velocity spindles testing should to a greater extent account for the former. This can be achieved by the innovative Precision Spindle Error Analyzer (SEA), which was implemented in the present study. Major applications of the system include: real-time monitoring of the spindle technical condition, potential spindle problem verification, spindle damage recognition (bearings, etc), evaluation of spindle condition at the stage of in-house testing and acceptance tests, verification of working order following crash. The present work analysed the capabilities and efficiency of precise detection of error motions (axial and radial) of the machine tool spindle. The presented modern diagnostics procedure, which derives from up-to-date ISO norms, concludes that innovation provides the basis for development of modern businesses. Implementation of new practices and heavily improved diagnostic methods, not to mention modern diagnostic tools is essential for any company to become innovative with regard to equipment and engineering process. Ideally, innovations in the field of engineering process 
should be reinforced by adequate production, organisation and marketing solutions. Not only should innovation in companies be predominantly put into practice for the strengthening of a company's competitiveness, it must also generate innovation within the company. Finally, innovation should be the essence of the primary activity of any enterprise.

\section{BIBLIOGRAPHY}

[1] ASHOK S. DENIS, SAMUEL G. L., Modeling, measurement, and evaluation of spindle radial errors in a miniaturized machine tool, International Journal of Advanced Manufacturing Technology, International Journal of Advanced Manufacturing Technology, 01/2012.

[2] BRINGMANN B., Improving Geometric Calibration Methods for Multi-axes Machining Centers by Examining Error Interdependencies Effects, Fortschritt-Berichte VDI, Dusseldorf, 2007.

[3] BRINGMANN B., KNAPP W. Model-based 'Chase-the-Ball' Calibration of a 5-Axes Machining Center, Annals of the CIRP, 55(1), 531-534, 2006.

[4] CEMPEL CZ., Podstawy wibroakustycznej diagnostyki maszyn, Warszawa, WNT, 1982.

[5] DZIERŻEK K., Analiza mechatronicznych układów pomiaru położenia, Białystok, Oficyna Wydawnicza Politechniki Białostockiej, 2009.

[6] FAN Kaiguo, YANG Jianguo, YANG Liyan, Orthogonal polynomials-based thermally induced spindle and geometric error modeling and compensation, International Journal of Advanced Manufacturing Technology, 65 (9-12).

[7] FLORUSSEN G.H.J., DELBRESSINE F.L.M., MOLENGRAFT M.J.G., SCHELLEKENS P.H.J., Assessing geometrical errors of multi-axis machines by three-dimensional length measurements, Measurement, 2001, 30, 241-255.

[8] IBARAKI S., IRITANI T., MATSUSHITA T., Error map construction for rotary axes on five-axis machine tools by on-the-machine measurement using a touch-trigger probe, International Journal of Machine Tools and Manufacture, 2013, 68

[9] IBARAKI S., IRUTANI T., MATSUSHITA T., Calibration of location errors of rotary axes on five-axis machine tools by on-the-machine measurement using a touch-trigger probe, International Journal of Machine Tools and Manufacture, 2012, 58, 44-53.

[10] JASTRZĘBSKI R., KRAJEWSKI, G., Metody diagnostyki błędów precyzyjnych stołów obrotowych $w$ obrabiarkach CNC, XIV Krajowa i V Międzynarodowa Konferencja Naukowo-Techniczna "Metrologia w Technikach Wytwarzania”, Pułtusk, 11-14 Września, 2011.

[11] JASTRZĘBSKI R., Metodyka badań elektro-wrzeciennika zabudowanego na obrabiarce, Sprawozdanie NH/B-05-2006, Centrum Badawczo-Konstrukcyjne Obrabiarek, 2006.

[12] JASTRZĘBSKI R., SZEPKE A., Badanie wptywu wybranych czynników na dokładność i stabilność pracy elektrowrzeciennika na przyktadzie centrum obróbkowego frezarskiego DIANA 1000, Sprawozdanie NH/B-012009, Centrum Badawczo-Konstrukcyjne Obrabiarek Sp. z o.o., 2009.

[13] JASTRZĘBSKI R., WELK A., Badanie dokładności obrabiarek sterowanych numerycznie. Badanie synchronizacji prędkości obrotowej wrzecion napędzanych silnikiem przez przekładnie pasowe we wrzeciennikach głównym i przechwytujacym zainstalowanych w tokarce Venus 350/750. Sprawozdanie NH/B03-2007, Centrum Badawczo-Konstrukcyjne Obrabiarek Sp. z o.o., 2007.

[14] JEMIELNIAK K., Analiza błędnych ruchów wrzecion szybkoobrotowych, Archiwum Technologii Maszyn i Automatyzacji, Wydział Inżynierii Produkcji, Politechnika Warszawska, Vol. 24, Nr 2. 2004.

[15] JÓZWIK J., KURIC I. SÁGA M., LONKWIC P., Diagnostics of CNC Machine Tools in Manufacturing Process with Laser Interferometer Technology. Manufacturing Technology, Vol. 14, No. 1, 2014, p. 23-30

[16] JÓZWIK J., KURIC I., GROZAV S., CECLAN V., Calibration of 5 axis CNC machine tool with 3D quickSET measurement system, Academic Journal of Manufacturing Engineering, ISSUE 1/2014, vol. 12

[17] JÓZWIK J., KURIC I., Non-contact diagnostic systems of CNC machine tools. Published by Scientific and Technical Society at the University of Zilina, Zilina, 2013.

[18] JÓZWIK J., PIEŚKO P., KRAJEWSKI G., Evaluation of QC10 Ballbar diagnostics method for CNC machine, Maintenance and Reliability, 2010, 3(47), 10-20.

[19] KUMARAN S., FUJII T., HOCKEN R., Simultaneous Measurement of spindle Error Motions: A Simple and Economical Method, Proc. of ASPE 1991 Ann. Conf., Santa Fe, NM, Oct. 1991.

[20] MAJDA P., Pomiary i kompensacja błędów geometrycznych obrabiarek CNC. Inżynieria Maszyn 2011, 16 (12), 126-134. 
[21] MAJDA P., The influence of geometric errors compensation of a CNC machine tool on the accuracy of movement with circular interpolation. Advances in Manufacturing Science and Technology, 2012, 36 (2), 59 67.

[22] MARCHELEK K., Dynamika obrabiarek, Warszawa, WNT, 1997.

[23] MARSH E. R., Precision Spindle Metrology. DEStech Publications, 2007, 10.

[24] MARTIN D.L., TABENKIN A.N., PARSONS F.G., Precision Spindle and Bearing Error Analysis, Int. J. Mach. Tools Manufact., Vol. 35, No.2, pp. 187-193, 1995.

[25] PAHK H. J., KIM Y.S., MOON J.H., A new technique for volumetric error assessment of CNC machine tools incorporating ball bar measurement and $3 D$ volumetric error model, International Journal of Machine Tools and Manufacture, 1997, 37(11), 1583-1596.

[26] PAHK H., LEE S.W., Thermal Error Measurement and Real Time Compensation System for the CNC, Machine Tools Incorporating the Spindle Thermal Error and the Feed Axis Thermal Error, International Journal of Advanced Manufacturing Technology, 08/2002.

[27] POSTLETHWAITE S.R., FORD D.G., MORTON D., Dynamic calibration of CNC machine tools, International Journal of Machine Tools and Manufacture, 1997, 37 (3), 287-294.

[28] ROBERT G., MARSH E., VALLANCE R., Techniques for calibrating spindles with nanometer error motion, Precision Engineering, 2005, 29: 113-123.

[29] SZTENDEL S., PISLARU C., LONGSTAFF A.P., FlETCHER S., MYERS A., Five-Axis Machine Tool Condition Monitoring Using dSPACE Real-Time System, Journal of Physics: Conference Series 364, 25th International Congress on Condition Monitoring and Diagnostic Engineering, 2012.

[30] TUREK P., KWAŚNY W., JĘDRZEJEWSKI J., Zaawansowane metody identyfikacji błędów obrabiarek, Inżynieria Maszyn, 2010, 5 (1-2), 8-37.

[31] VELDHUIS S.C., ELBESTAWI M.A. A, Strategy for the Compensation of Errors in Five-Axis Machining, CIRP Annals - Manufacturing Technology, 1995, 44(1), 373-377.

[32] WEIKERT S., R-Test, a New Device of Accuracy Measurements on Five Axis Machine Tools, CIRP Annals, $2004,53,1,429$.

[33] WOŹNIAK, A., BYSZEWSKI, M., JANKOWSKI, M., KRAJEWSKI, G., Spatial Characteristics of the Triggering Force of Touch Probes for CNC Machine Tools, 2nd International Conference on Virtual Machining Process Technology, McMaster University, Hamilton, Ontario, Canada, May 13-17, 2013.

[34] WU L.S., YANG Y., ZHOU D.S., Dynamic Measurement Technology of the Spindle Motion Error of High Speed Spindle, Aviation Precision Manufacturing Technology, 2008, 44(4):26-29.

[35] WYSOCKI P., Opracowanie metody pomiarów sztywności statycznej $w$ oparciu o tory pomiarowe przemieszczeń liniowych. Sprawozdanie NB-30-1998, Centrum Badawczo-Konstrukcyjne Obrabiarek, 1998.

[36] ZHAO XUESEN, SUN TAO, YAN YONGDA, HU ZHENJIANG AND DONG SHEN, A new rotational error measurement method for precision spindle based on the registration analysis of motion topography. The 10th International Symposium of Measurement Technology and Intelligent Instruments. June $29-$ July 2 2011/1.

\section{ISO Standards and PN-ISO Standards}

[37] PN-ISO 230-1:1998 Przepisy badania obrabiarek. Dokładność geometryczna obrabiarek pracujących bez obciążenia lub w warunkach obróbki wykańczającej.

[38] ISO 230-7: 2006 Test code for machine tools - Part 7: Geometric accuracy of axes of rotation.

[39] ISO 230-3:2007 Test code for machine tools - Part 3: Determination of thermal effects.

Web pages

[40] http://sites.mech.ubc.ca/ xdlu/files/TwoD_ErrorMotion_Special_Presentation.ppsx, (20.10.2014).

[41] http://blog.aerotechmotioncontrol.com/2012/12/20/rotary-stage-terminology, (20.10.2014).

[42] http://www.lionprecision.com/products.html, (20.10.2014).

[43] http://www.ibspe.com, (20.10.2014). 